\title{
FGFR3 Gene Rearrangement Negative
}

National Cancer Institute

\section{Source}

National Cancer Institute. FGFR3 Gene Rearrangement Negative. NCI Thesaurus. Code C160366.

A genetic finding indicating that rearrangement of the FGFR3 gene has not been detected in a sample. 